DOI

UDC: 616.153.455.01:616.8-008.615.1:616.383-092]:611-018.26:612.349.8:546.221]-092.9

\title{
HYDROGEN SULFIDE SYSTEM ATTENUATES INJURY BY HYPERGLYCEMIA AND STRESS: THE ROLE OF MESENTERIC ADIPOCYTES IN AGED ANIMALS
}

\author{
Oleh Revenko', Natalia Zaichko², John Wallace ${ }^{3}$, Oksana Zayachkivska1 \\ 1 Department of Physiology of Lviv National Medical University, Lviv, \\ Ukraine, ${ }^{2}$ Department of Biological and General Chemistry of National \\ Pirogov Memorial Medical University, Vinnytsia, Ukraine, ${ }^{3}$ Department of \\ Physiology and Pharmacology, University of Calgary, Calgary, Canada \\ wersus35@gmail.com
}

\begin{abstract}
Introduction. The mesentery is one of the recently described separate organs, whose functions and ability to protect itself from injuries are still unclear. Adipocytes are a part of the mesentery (MAC); however, little is known about their age-related changes, responses at times of damage induced by hyperglycemia, stress, and their interaction. Hydrogen Sulfide $\left(\mathrm{H}_{2} \mathrm{~S}\right)$ system is a key endogenous cytoprotective system that operates by catalytic activities of Cystathionine- $y$-lyase (CSE), Cystathionine- $\beta$-synthase (CBS), and Sulfite Oxidase (SUOX) but their role in adipocyte cytoprotection is still unknown.
\end{abstract}

Aim. To evaluate the CBS, CSE, SUOX activities in the mesenterium and ultrastructural changes of MAC in aged rats fed with HSD, under conditions of stress, their combination, and modification of $\mathrm{H}_{2} \mathrm{~S}$ synthesis: by injecting NaHS and hybrid nonsteroid anti-inflammatory drug, which is rich in $\mathrm{H}_{2} \mathrm{~S}$-acetylsalicylic acid $\left(\mathrm{H}_{2} \mathrm{~S}-\mathrm{ASA}\right)$.

Material and Methods. The research was conducted on old rats, divided into the control group (animals were on the standard diet and received $1.0 \mathrm{ml}$ of $0.9 \% \mathrm{NaCl}$ solution per os); accordingly, the remaining animals with HSD in per os groups received 2) $1.0 \mathrm{ml}$ of $0,9 \% \mathrm{NaCl}$ solution; 3) NaHS at a dose of $100 \mathrm{mcM} / \mathrm{kg} /$ day, 9 days; 4) $1.0 \mathrm{ml}$ of $0.9 \% \mathrm{NaCl}$ solution, 9 days, and stress induction (Takagi, K, 1964); 5) NaHS at a dose of $100 \mathrm{mcM} / \mathrm{kg}$, 9 days, and stress induction; 6) ASA in the dose of $10 \mathrm{mg} / \mathrm{kg} / \mathrm{day}, 9$ days, NaHS at a dose of $100 \mathrm{mcM} / \mathrm{kg}$, and stress induction; 7) ASA, $10 \mathrm{mg} / \mathrm{kg} /$ day, 9 days, and stress induction; 8) H2S-aspirin (H2S-ASA, ATB-340), $17.5 \mathrm{mg} / \mathrm{kg} /$ day, 9 days, and stress induction. Subcellular modifications of adipocytes were researched using the transmission electronic microscopy (TEM). CSE, CBS, SUOX enzyme activity was assessed using the standard biochemical methods.

Results. In groups of animals with HSD and NaHS, no structural destructive changes were identified on the endothelial and subendothelial level; uneven chromatin condensation was observed in the nucleus of endothelial cells. The impact of hybrid $\mathrm{H}_{2} \mathrm{~S}$-aspirin had a protective effect and led to the "loss" of mesenteric adipocytes. Administration of the hybrid aspirin led to an increase by $15 \%$ of the general $\mathrm{H}_{2} \mathrm{~S} / \mathrm{CSE}$ i $\mathrm{H}_{2} \mathrm{~S} / \mathrm{CBS}$ activity as compared to the effect of the regular aspirin $(p<0,05)$. Using the aspirin along with $\mathrm{NaHS}$ led to the $67 \%$ increase in $\mathrm{H}_{2} \mathrm{~S} / \mathrm{CSE}$ i $\mathrm{H}_{2} \mathrm{~S} / \mathrm{CBS}$ activity in rats with HSD as compared to the group receiving normal saline. SUOX activity constituted $5.27 \mathrm{nM} / \mathrm{min} \bullet \mathrm{mg}$ in the control group, $4.05 \mathrm{nM} / \mathrm{min} \times \mathrm{mg}$ in rats with HSD; in the groups of HSD with NaHS and stress, the obtained values were approximately equal to control values

Conclusions. This study confirms the important role of CSE/H2S pathway in the life of mesenteric adipocytes and its cytoprotective effect. The high activity of the expression of CSE and 
SUOX pathways in case of H2S synthesis in mesenteric adipocytes and disorders caused by age and hyperglycemia may be related to the development of non-specific inflammation and potentially used to treat obesity. H2S-aspirin may become an effective drug for prevention of age-related inflammation and may have a protective effect in case of hyperglycemia.

Disclosures. No conflicts of interest, financial or otherwise, are declared by the authors.

Author contribution. Oleh Revenko drafted manuscript; Natalia Zaichko edited and revised manuscript; John Wallace, Oksana Zayachkivska approved final version of the manuscript.

Key words: Gasotransmitters, Hydrogen Sulfide, Cystathionine- $\beta$-synthases, Cystathionine- $\gamma$ lyase, Sulfite Oxidase, mesenterium, fat tissue, cellular cytoprotection, inflammation, glucose homeostasis, age-related changes

\title{
СІРКОВОДНЕВА СИСТЕМА ЗМЕНШУЄ УШКОДЖЕННЯ АДИПОЦИТІВ БРИЖІ У СТАРИХ ТВАРИН, ІНДУКОВАНІ ГIПЕРГЛІКЕМІЄЮ ТА СТРЕСОМ
}

\author{
Олег Ревенко1, Наталія Заічкоㄹ, Джон Л. Уоллес³, Оксана Заячківська ${ }^{1}$ \\ ${ }^{1}$ Кафедра нормальної фізіології, Львівський національний медичний уні- \\ верситет ім.Данила Галицького, Львів, Україна, \\ 2 Кафедра біологічної та загальної хімії, Вінницький національний медич- \\ ний університет ім. М.І.Пирогова, Вінниця, Україна, \\ ${ }^{3}$ Кафедра фізіології та фармакології, Університет Калгарі, Калгарі, Канада \\ wersus35@gmail.com
}

\begin{abstract}
Вступ. Брижа - новий нещодавно відкритий орган людського тіла. Однак функціональне значення брижі як органу травної системи та ї̈ роль у захисних механізмах організму залишаються нез'ясованими. Мезантеріальні адипоцити (МА) $\epsilon$ частиною брижі, проте мало відомо про їхні вікові зміни, реактивні відповіді за індукції гіперглікемії, стресу та їхнього поєднаного впливу. Фізіологічні ефекти сірководню $\left(H_{2} S\right) \in$ ключовими для ендогенної системи цитопротекції, яка функціонує за допомогою каталітичної активності цистатионін- $ү$-ліази (CSE), цистатіонін- $\beta$-синтази (CBS) і сульфіт-оксидази (SUOX), але їхня роль у цитопротекції адипоцитів ще не з'ясована.
\end{abstract}

Мета. Дослідити активність цистатіонін- $\beta$-синтази (CBS), цистатионін- $\gamma$-ліази (CSE), сульфіт-оксидази (SUOX) брижі та дослідження ультраструктурних змін MA у старих щурів за умов висококалорійної високовуглеводної дієти (HSD), стресу, їхнього поєднання і модифікації синтезу сірководню $\left(\mathrm{H}_{2} \mathrm{~S}\right)$ : введення $\mathrm{NaHS}$ та сполуки гібридного нестероїдного протизапального препарату, збагаченої $\mathrm{H}_{2} \mathrm{~S}-\mathrm{H}_{2} \mathrm{~S}$-аспірину ( $\left.\mathrm{H}_{2} \mathrm{~S}-\mathrm{ASA}\right)$.

Матеріали та методи. Дослідження проводили на старих щурах, виділяли контрольну групу (тварини перебували на стандартній дієті й отримували 1,0 мл 0,9\% $\mathrm{NaCl}$ p-ну per os), решта тварин з HSD отримували, відповідно, у групах per os: 2) 1,0 мл 0,9\% $\mathrm{NaCl} \mathrm{p-нy;} \mathrm{3)} \mathrm{NaHS}$ в дозі 100 мкмоль/кг/добу, 9 днів; 4) 1,0 мл 0,9\% NaCl р-ну 9 днів і індукцію стресу (Takagi, K, 1964); 5) NaHS в дозі 100 мкмоль/кг 9 днів і індукцію стресу; 6) АСК в дозі 10 мг/кг/добу 9 днів, NaHS в дозі 100 мкмоль/кг та індукцію стресу; 7) АСК, 10 мг/кг/добу, 9 днів та індукцію стресу; 8) $\mathrm{H}_{2} \mathrm{~S}$-аспірин ( $\mathrm{H}_{2} \mathrm{~S}-\mathrm{ASA}$, ATB-340), 17,5 мг/кг/добу, 9 днів та індукцію стресу. Субклітинні зміни мезантеріальних адипоцитів досліджували за допомогою трансмісивної електронної мікроскопії (TEM). Активність ензимів CSE, CBS, SUOX оцінювали стандартними біохімічними методами. 
Результати. У групі тварин з HSD та NaHS структурних деструктивних змін на ендотеліальному та субендотеліальному рівні не було виявлено, у ядрі ендотеліальних клітин спостерігалася нерівномірна конденсація хроматину. Вплив гібридного $\mathrm{H}_{2} \mathrm{~S}$-аспірину виявився захисною дією $i$ «схудненням» мезантеріальних адипоцитів. Застосування гібридного аспірину виявило збільшення на $15 \%$ загальної активності $\mathrm{H}_{2} \mathrm{~S} / \mathrm{CSE}$ і $\mathrm{H}_{2} \mathrm{~S} / \mathrm{CBS}$ на противагу від дії звичайного аспірину ( $p<0,05)$. Використання аспірину одночасно з NaHS виявило збільшення на 67\% активності $\mathrm{H}_{2} \mathrm{~S} / \mathrm{CSE}$ i $\mathrm{H}_{2} \mathrm{~S} / \mathrm{CBS}$ у щурів HSD при порівнювані до групи, що отримувала фізрозчин. Активність SUOX становила 5,27 нмоль/хв•мг у контрольній групі, у щурів на HSD - 4,05 нмоль/хв•мг; у групі на HSD з NaHS і дією стресу отримані значення приблизно дорівнювали контрольним.

Висновки. Дослідження свідчить про важливу роль CSE/H $\mathrm{H}_{2} \mathrm{~S}$ шляху у життєдіяльності мезантеріальних адипоцитів і його цитопротекторну дію. Висока активність експресії шляхів CSE та SUOX при синтезі $\mathrm{H}_{2} \mathrm{~S}$ у мезентеріальних адипоцитах, при порушеннях зумовлених віком і гіперглікемією може бути пов'язана з розвитком неспецифічного запалення, мати потенційне використання $з$ терапевтичною метою для лікування ожиріння. $\mathrm{H}_{2} \mathrm{~S}$-аспірин може стати ефективним засобом для запобігання вікового неспецифічного запалення, мати захисний ефект при гіперглікемії.

Ключові слова: Газотрансмітери, сірководень, цистатіонін- $\beta$-синтази, цистатіонін- $\gamma$-ліаза, сульфіт оксидаза, брижа, жирова тканина, клітинна цитопротекція, запалення, гомеостаз глюкози, вікові зміни

The prevalence of obesity and its comorbidities worldwide, including Ukraine, is increasing especially among adults in the last two decades (Fig.1). Recently this pathology was considered as a major medical problem which is attributed to the influence of the modern Western diet, rich in high caloric high sugar diet (HSD) [18].

Ectopic accumulation of visceral fat mass related to the HSD induces low grade inflammation [5] which has harmful effects on cellular survive, as well as inducing cell injury/death, changes in the microbiome and cancer development $[1,4,12,18]$.
The mesentery is one of recently described separate organs which functions and its ability to protect injury are still unclear [8]. Adipocytes are a part of mesentery, however, it is a little known about their age-related changes, reactive response during damage induced by hyperglycemia, stress, and their interaction, as well as association with low grade inflammation $[15,28]$.

Among several recently described key peripheral factors of cytoprotection is Hydrogen Sulfide $\left(\mathrm{H}_{2} \mathrm{~S}\right)$ system that endogenously generates gas by the pyridoxal $5^{\prime}$ phosphate $\left(B_{6}\right)$-dependent enzyme catalytic activities

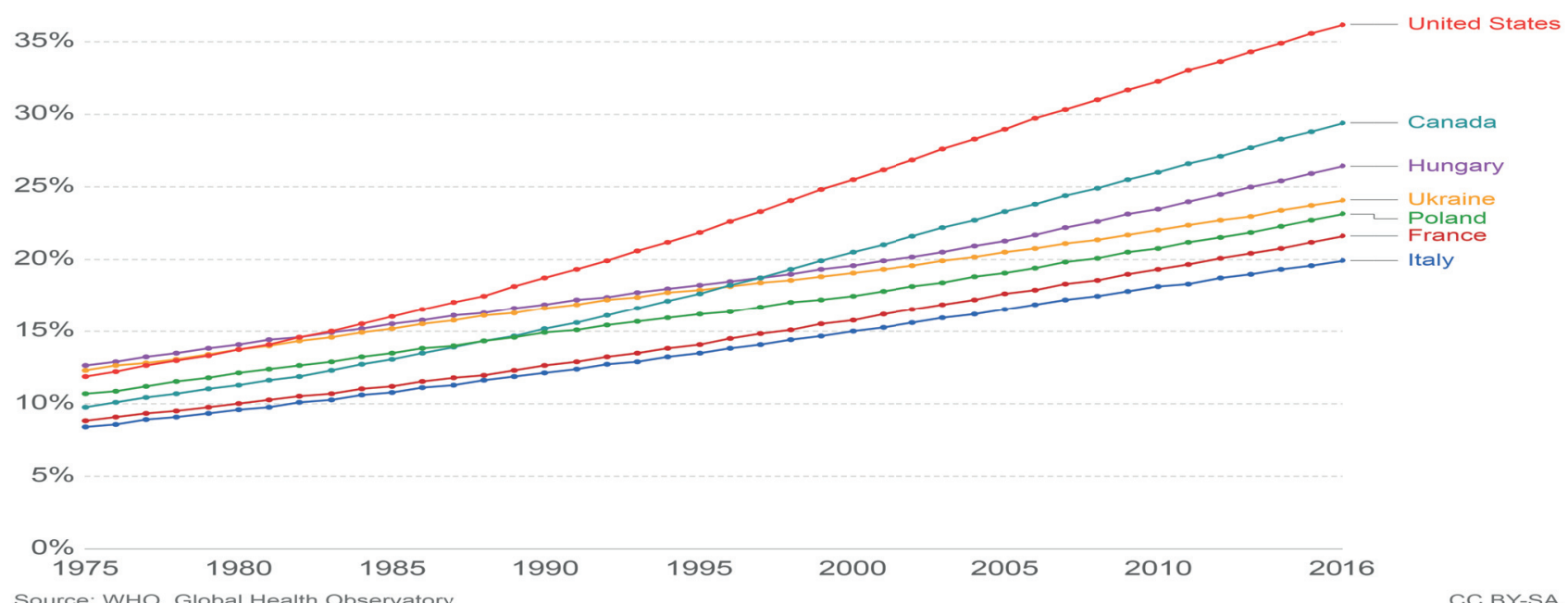

Fig. 1. The prevalence of obese adults aged $18+$ in Ukraine, Hungary, Poland, Italy, France, Canada, and United States of America based on their body mass index which is greater or equal to 30 in WHO report (2017) 
of Cystathionine- $y$-lyase (CSE, EC 4.4.1.1), Cystathionine- $\beta$-synthase (CBS, EC 4.2.1.22 ), and 3-mercaptopyruvate sulfurtransferase (EC 2.8.1.2) by Cysteine aminotransferase (CAT), which use L-cysteine as a substrate, and non-enzymatic production of $\mathrm{H}_{2} \mathrm{~S}$ by glucose [23], glutathione [19] which are essential for anti-inflammatory, anti-radical scavenged effects (e.g. by methemoglobin, metallo or disulfide containing molecules, and oxidized glutathione), vasodilatation, cytosolic methylation (via $S$ methyltransferase), mitochondrial oxidation (e.g. oxidization to thiosulfate, which is eventually converted to sulfite and sulfate by Sulfite Oxidase (EC 1.8.3.1, SOX) $[2,12$, $20,24]$, as well as from inorganic and organic polysulfides and elemental sulfur $[13,14]$ and microbiome $[4,16,26]$. The previous data of cytoprotective and anti-inflammatory effects of $\mathrm{H}_{2} \mathrm{~S}$-containing compounds of non-steroidal anti-inflammatory drugs (NSAID) naproxen (ATB 346) on vascular tone, including vascular ageing $[24,27,30]$, is very promising for future fat tissue investigation, which is an active source of endocrine factors according to the novel data [7]. Recently, it was demonstrated that relationship between $\mathrm{H}_{2} \mathrm{~S}$ pathway, adipogenesis, inflammation, and fat mass accumulation is controversial, as both stimulation and inhibition have been reported [28]. These observations, together with the known opposite effects of $\mathrm{H}_{2} \mathrm{~S}$ on glucose homeostasis (Tab.1) in the regulation of insulin secretion and insulin sensitivity, promoted us to further investigate the effect of $\mathrm{H}_{2} \mathrm{~S}$ by activities of its enzymes CBS, CSE, SUOX in the mesenterial adipocytes via determination their changes during induced injury in animal model of the pre-metabolic syndrome by hyperglycemia (HSD), induction of acute stress and modulation of cytoprotection by eicosanoid biosynthesis via NSAID and exogenous modification of $\mathrm{H}_{2} \mathrm{~S}$ pathway activities by $\mathrm{H}_{2} \mathrm{~S}-\mathrm{NSAID}[17,21]$.

Aim. To evaluate the CBS, CSE, SUOX activities in the mesenterium and ultrastructural changes of mesenteric adipocytes (MAC) in aged rats fed with HSD, at stress induction, and modification of $\mathrm{H}_{2} \mathrm{~S}$ synthesis.

Material and Methods. All experiments were carried out on the aged rats ( $N=48$, body weight $350 \pm 40 \mathrm{~g} ; \mathrm{n}=5-7)$ in accordance with the norms of the European Convention for the Protection of Vertebrate Animals Used for Experimental and Other Scientific Purposes (1986) and in accordance with the Committee on Bioethics of Danylo Halytsky Lviv National Medical University agreement 4 from 23.04.2018. Animals were maintained under a constant $12 \mathrm{~h}$ light and dark cycle and an ambient temperature of C with $50 \pm 10 \%$ relative humidity. All animals were kept in raised mesh-bottom cages to prevent coprophagy. Animal from the control group were allowed free access to tap water and kept on standard diet, other rats experimental groups on 28-days hypercaloric high-carbohydrate diet, as HSD by V. Kozar, 2008, with unrestricted access to $40 \%$ solution of fructose ad libitum within drinking-water $[5,15]$. The rats consequently underwent euthanasia under deep by ketamine anaesthesia $\left(60 \mathrm{mkg} / \mathrm{kg}^{-1}\right.$ ) via intramuscular administration and sample of paired samples of MAC were obtained from the area contiguous with the ileum. Subcellular changes if MAC by morphological techniques via transmission electron microscopy (TEM) were used to detect the characteristics of the rat MAC in normal condition and during injury, and compare them with the characteristics of the control tissues [8]. Fixation of the material for electron microscopy was carried out with a $2 \%$ solution of osmium oxide (OsO4) eV $0.1 \mathrm{~mol} / \mathrm{L}$ phosphate buffer. Then the processing of the material was conducted according to generally accepted methods. Ultrathin cuts $(30-60 \mathrm{~nm})$ were produced on ultratome «UMTP-3M» and after coloring with Reynolds, they were photographed and studied with an electron microscope «UEMV-100K» (Ukraine) on an increase in 2,500, 3,000, 5,000,6,000, $8,000,10,000$ and 15,000 times.

Table 1

Effects of $\mathrm{H}_{2} \mathrm{~S}$ on glucose homeostasis Hypoglycemia Hyperglycemia $(<70 \mathrm{mg} / \mathrm{dl}) \quad(>200 \mathrm{mg} / \mathrm{dl})$

\begin{tabular}{|c|c|}
\hline$\downarrow$ Lipolys in adipocytes & $\begin{array}{c}\downarrow \text { Insulin secretion from } \\
\beta \text {-cells }\end{array}$ \\
\hline $\begin{array}{l}\uparrow \text { Glucose uptake into } \\
\text { skeletal muscle }\end{array}$ & $\begin{array}{l}\uparrow \text { Hepatic glucose pro- } \\
\text { duction }\end{array}$ \\
\hline $\begin{array}{c}\uparrow \text { Glucose uptake into } \\
\text { fat }\end{array}$ & $\begin{array}{l}\downarrow \text { Glucose uptake into } \\
\text { hepatocytes }\end{array}$ \\
\hline
\end{tabular}

For the objectives of the study and determination the role of $\mathrm{H}_{2} \mathrm{~S}$ pathway in the mechanisms of mesenterial adipocyte cytoprotection in old rats by activities of CSE, CBS and SUOX that 
catalyzes the physiologically vital oxidation of sulfite to sulfate, the terminal reaction in the oxidative degradation of the sulfur-containing amino acids cysteine and methionine, were inducted acute stress by water-immobilization stress model by Takagi, 1964, 1968 [21, 22], and animals were treated by hybrid $\mathrm{H}_{2} \mathrm{~S}$ associated NSAIDs compounds with comparison to classical NSAIDs analogues $[10,11]$. The design of study is represented on Fig. 2 .

The animals were subdivided into groups and pretreated per os by: 1) control group with standard diet and by vehicle $(1,0 \mathrm{ml}$ of saline), rats from 2-8 groups had HSD and for 2) $1,0 \mathrm{ml}$ of saline; 3) NaHS in a dose of 100 $\mathrm{mkmol} / \mathrm{kg}$, 9 days $10 \mathrm{mg} / \mathrm{kg} /$ day; 4) $1,0 \mathrm{ml}$ of saline and induction of stress; 5) NaHS at a dose of $100 \mathrm{mkmol} / \mathrm{kg}$ and induction of stress; 6) ASA at a dose of $10 \mathrm{mg} / \mathrm{kg} /$ day for 9 days, per os, NaHS at a dose of $100 \mathrm{mkmol} / \mathrm{kg}$, per os, and induction of stress; 7) ASA, manufactured by Darnitsa, Ukraine, $10 \mathrm{mg} / \mathrm{kg} /$ day, per 9 days; 8) $\mathrm{H}_{2} \mathrm{~S}$-aspirin ( $\mathrm{H}_{2} \mathrm{~S}-\mathrm{ASA}$, ATB-340), manufactured by Antibes, Canada, $17,5 \mathrm{mg} /$ $\mathrm{kg} /$ day, per 9 days). The administration of NaHS and ATB-340 was performed in doses tested by J.L. Wallace, 2012-2017 [24-26].

Evaluation of rat survival rate, basal conditions, expression of CSE, CBS, SUOX activities in $M A C$ were done by standard biochemical meth- ods [28]. The required statistical calculations and diagramming were prepared using IBM PC Pentium computer with STATISTICA for Windows 5.0 software and Microsoft Excel spreadsheets. The distribution of parametric indices in the samples was normal (Gaussian) - Shapiro-Wilk's W-test. Due to the presence of more than two study groups, parametric characteristics were compared using a post-test analysis (ANOVA unit - analysis of variance), where mean values were compared in pairs using the Newman-Keuls criterion. Data were considered valid when $*-p<0.05, *-p<0.01$.

Results and Discussion. Mass-metric studies in animals of experimental groups did not reveal significant differences (up to $10-12 \%)$ from the control group data. The rat glycemia data did not show any changes other than the control group. According to the results of investigation ultrastructural changes of MAC by electron microscopy (Fig. 3), it was determined that under normal conditions the small intestine mesentery is represented by adipose tissue of the regular histological structure with regional lymph nodes and wellpreserved endothelial cells and the basal membrane of the habitual structure (Fig. 3,a).

In rats fed with HSD, the mesentery contained plethoric vessels, occasionally there was fluttering basal membrane of hemocapillaries. The

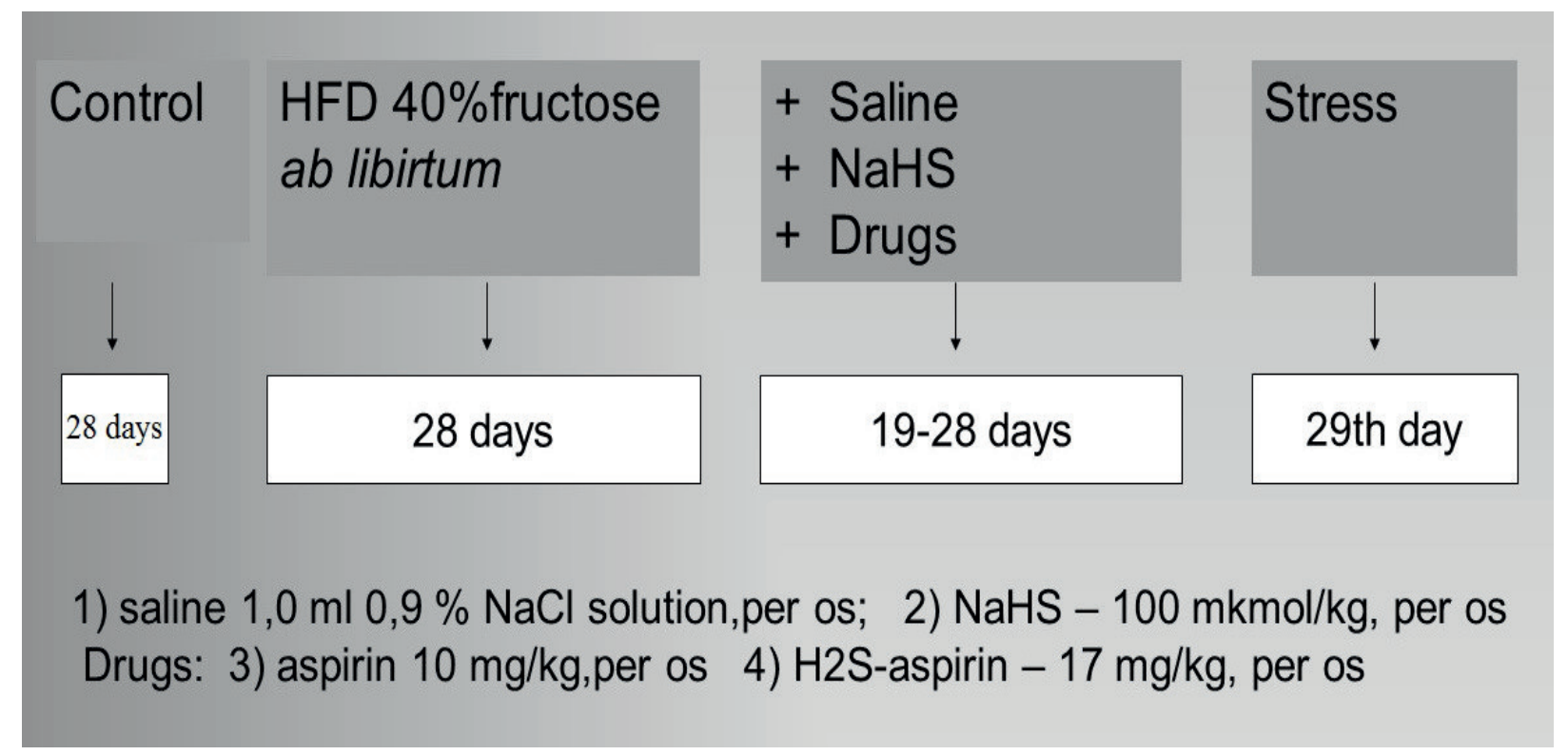

Fig.2. The scheme of study design; SD - standard diet; HSD - high sugar diet 
white fat adipose tissue adipocytes have been unevenly enlarged. There was also observed a large number of heterogeneous mitochondria with an enlightened matrix, loosening of the basement membrane reflecting the adaptive-compensating adaptive reactions for hyperglycemia.

In animals with HSD and pretreatment of $\mathrm{NaHS}$, non-organic compound that raises amount of $\mathrm{H}_{2} \mathrm{~S}$ in tissues, such signs were absent. In the nucleus of endothelial cells it was observed an uneven condensation of chromatin, while signs of endothelium and sub-endothelial structures violations were absent (Fig. 3,b).

Vacuuming of fat inclusions in the MAC under conditions of ASA injection along with the vac- uolated fragments of fat inclusions is observed (Fig. 3,c). There is also observed an accumulation of a large number of small electron dense mitochondria. This is an indirect sign that indicates the activation of mitochondrial breathing processes. In animals receiving aspirin, there were signs of swelling of the blood vessel walls, mesenteric adipocytes of considerable size and filled with lipid drops of average electron density. The use of a hydrogen sulfide natural synthesis donor in a hybrid $\mathrm{H}_{2} \mathrm{~S}$-aspirin compound according to the electronic microscopy showed changes characterized by the preservation of intercellular contacts that could be interpreted as a protective action and reducing the size of adipocytes «slimming» (Fig 3,d). Similar results were obtained during other studies $[1,21]$.

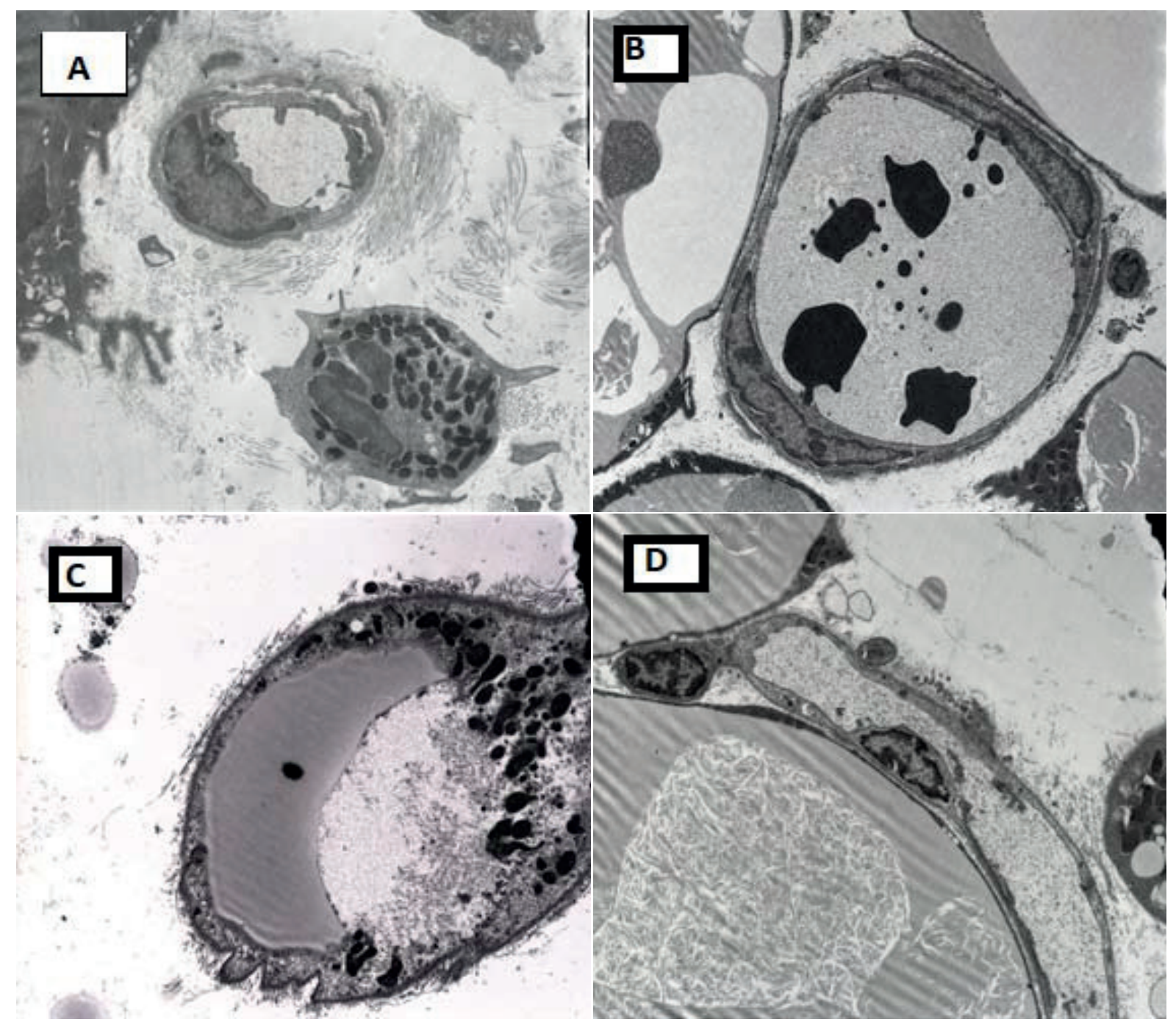

Fig. 3. Results of electron microscopy of rat mesenteric adipocytes with standard diet and pretreated by saline (a); $\operatorname{NaHS}(b)$; aspirin $(c), \mathrm{H}_{2} \mathrm{~S}$-aspirin $(d)$ during 28 days high fructose diet (b-d); Bar: in $\mathrm{A}, 1.6 \mu \mathrm{m}$; and in $\mathrm{B}, 0.2 \mu \mathrm{m}$ 
It is known that the characteristic feature of the $\mathrm{H}_{2} \mathrm{~S}$ effect is the modulation of protective qualities in the body that can be evaluated by the activity of CSE and CBS [2, 3, 19]. We examined how the regulatory influence of the hydrogen sulfide on MAC by the activities of CSE and CBS/ as well as SUOX under the modification of the hydrogen sulfide formation by pretreatment of the $\mathrm{H} 2 \mathrm{~S}$, hybrid $\mathrm{H}_{2} \mathrm{~S}$-aspirin application versus the effect of classical aspirin (ASA) in rats with HSD and induction stress injury (Fig.4, 5].

The average values of CSE and CBS activities in the MAC of rat control group were 1.01 $\mathrm{nmol} \mathrm{H}_{2} \mathrm{~S} /$ min $\bullet \mathrm{mg}$ protein and $0.75 \mathrm{nmol} \mathrm{H}_{2} \mathrm{~S} /$ min॰mg protein, respectively. In rats of the «relative control» group with 28-days hyperglycemia and saline administration the CSE activity was $1.21 \mathrm{nmol} \mathrm{H}_{2} \mathrm{~S} / \mathrm{min} \bullet \mathrm{mg}$ protein for, and for CBS $\quad 0.89 \mathrm{nmol} \mathrm{H}_{2} \mathrm{~S} / \mathrm{min} \bullet \mathrm{mg}$ protein $(p<0.05)$. The pretreatment of NaHS caused an increase in CSE activity on 37\% compared with the control group $(p<0.05)$, while under stress it decreased to $27 \%(p<0.05)$. The activity of CBS did not undergo significant changes in the application of $\mathrm{NaHS}$, the value remained at the level of benchmarks $(p<0.05)$.

Under the influence of stress the CSE activity in the group that received saline decreased to 0.69 $\mathrm{nmolH} \mathrm{H}_{2} \mathrm{~S} / \mathrm{min} \bullet \mathrm{mg}$ protein or to $44 \%$ compared to the «relative control» group of HSD $(p<0.05)$ and for $32 \%$ to the control group $(p<0.05)$ on $\mathrm{SD}$. Under the influence of stress, the value of CBS activity in the group of animal that received saline was the opposite, it increased on $42 \%$ relatively to the HSD group and on $70 \%$ relatively to the control group $(p<0.05)$.

The effect of aspirin on MAC under the influence of stress caused various effects on the activities of CSE and CBS. There was the increased of CSE on $33 \%$ compared to the saline group, while the activity of CBS decreased on $19 \%$ in comparison CSE activity on to animal with stress-induced damage and saline pretreatment. Obtained results could be explained by induction low-grade inflammation, regarding to the previous our data of pro- and anti-inflammatory cytokines expressions [24, 25, 29, 30].

The use of the hybrid aspirin led to even more significant increase activity of CSE on $81 \%$ and a slight decrease on $16 \%$ for CBS in comparison to animal with stress-induced damage and saline pretreatment. The use of the aspirin and NaHS showed an increase in 2.7 times of CSE activity and the absence of changes in CBS activity compared to the data of the control group $(p<0.01)$.

The result of the general activity of CSE and CBS in MAC showed the average data in the control group was $2 \mathrm{nmol} \mathrm{H}_{2} \mathrm{~S} /$ min $\bullet \mathrm{mg}$ protein, in rats of the «relative control» group with $\mathrm{HSD}$ it was $2.11 \mathrm{nmol} \mathrm{H}_{2} \mathrm{~S} /$ min $\bullet \mathrm{mg}$ protein. The use of NaHS caused an increase in general activity of $\mathrm{H}_{2} \mathrm{~S} / \mathrm{CSE}$ and $\mathrm{H}_{2} \mathrm{~S} / \mathrm{CBS}$ on $14 \%$ compared to the control group $(p<0.05)$.

Under the influence of stress, the general activity of $\mathrm{H}_{2} \mathrm{~S} / \mathrm{CSE}$ and $\mathrm{H}_{2} \mathrm{~S} / \mathrm{CBS}$ did not undergo significant changes and remained on the value of the control group $(p<0.05)$.

The effect of aspirin under the influence of stress at the general calculation did not reveal any changes in general activity of $\mathrm{H}_{2} \mathrm{~S}$ / CSE and $\mathrm{H}_{2} \mathrm{~S} / \mathrm{CBS}$ vs saline pretreatment $(p<0.01)$. The use of hybrid aspirin showed an increase on $15 \%$ of the general activity of $\mathrm{H}_{2} \mathrm{~S} / \mathrm{CSE}$ and $\mathrm{H}_{2} \mathrm{~S} / \mathrm{CBS}$ in composition to rats with ASA pretreatment $(p<0.05)$. The use of aspirin and NaHS has shown an increase on $67 \%$ of the general activity of $\mathrm{H}_{2} \mathrm{~S} / \mathrm{CSE}$ and $\mathrm{H}_{2} \mathrm{~S} / \mathrm{CBS}$ compared to the values of the saline group.

The average value of Sulfite oxidase (SUOX) in the control serum of blood was $5.27 \mathrm{nmol} /$ min॰mg protein, in rats of the «relative» control group with 28-day hyperglycemia was $4.05 \mathrm{nmol} / \mathrm{min} \bullet \mathrm{mg}$ protein (Fig. 5). The use of NaHS under HSD and stress conditions did not cause SUOX changes comparable to the control. These results could be explained by metabolic changes in energy induced by acute stress $[12,18]$.

Under the influence of stress, SUOX in the saline group decreased on $26 \%$ compared with the control group.

The effect of aspirin under the influence of stress has led to a $35 \%$ reduction in SUOX compared to the control group. The use of the hybrid aspirin has led to an increase in SUOX values on 
$18 \%$ relatively to the control, while compared to the saline group to $60 \%$ growth. The use of aspirin and NaHS together showed a similar result.

Conclusions. This study suggests an important role for $\mathrm{CSE} / \mathrm{H}_{2} \mathrm{~S}$ pathway in the mesenteric adipocyte cellar survival and control cytoprotection.

Novel findings relating to high expression activities in $\mathrm{CSE} / \mathrm{H}_{2} \mathrm{~S}$ and SUOX pathways in mesenteric adipocytes compromised by age, hyperglycemia and stress might be associated with the development of low-grade in- flammation and may be a potential therapeutic target for obesity treatment. $\mathrm{H}_{2} \mathrm{~S}$ aspirin could be an effective tool for prevention of age-related inflammation and exert defensive effect against hyperglycemia.

Disclosures. No conflicts of interest, financial or otherwise, are declared by the authors.

Author contribution. Oleh Revenko drafted manuscript; Natalia Zaichko edited and revised manuscript; John Wallace, Oksana Zayachkivska approved final version of the manuscript.

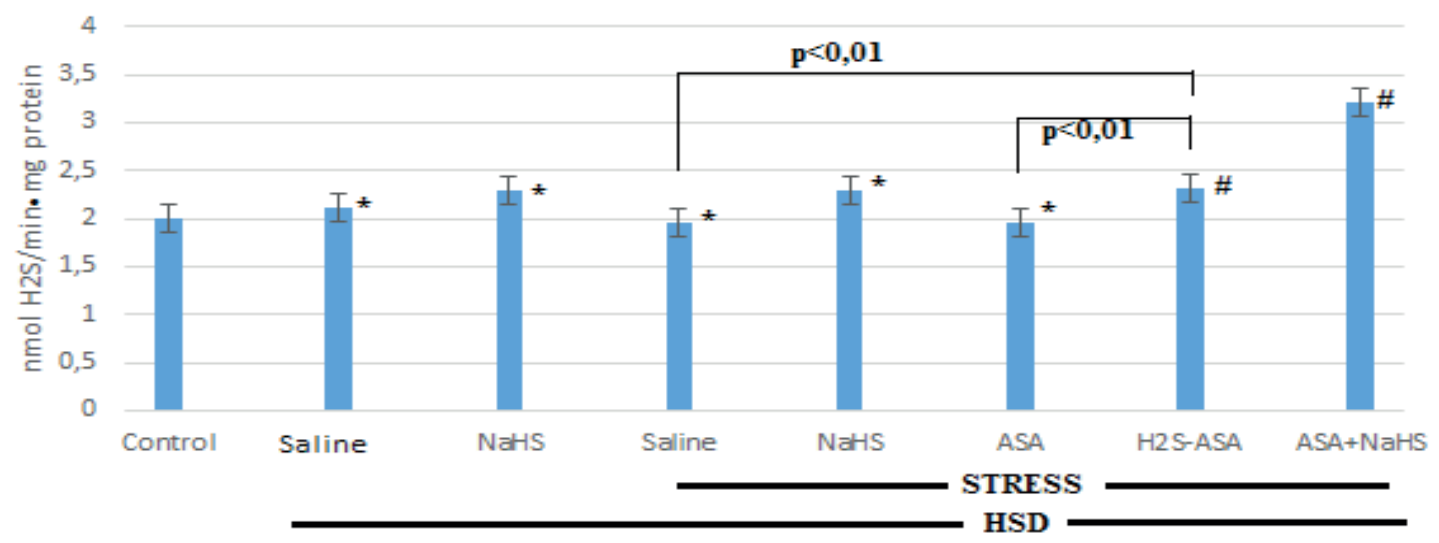

${ }^{*} \mathrm{p}<0,05 \# \mathrm{p}<0,01 \mathrm{p}$ vs control

Fig. 4. Changes in activities of CSE and CBS in mesenterium adipocytes of control and experimental groups of rats

\section{Changes in activity of Sulfite oxidase (SUOX)}

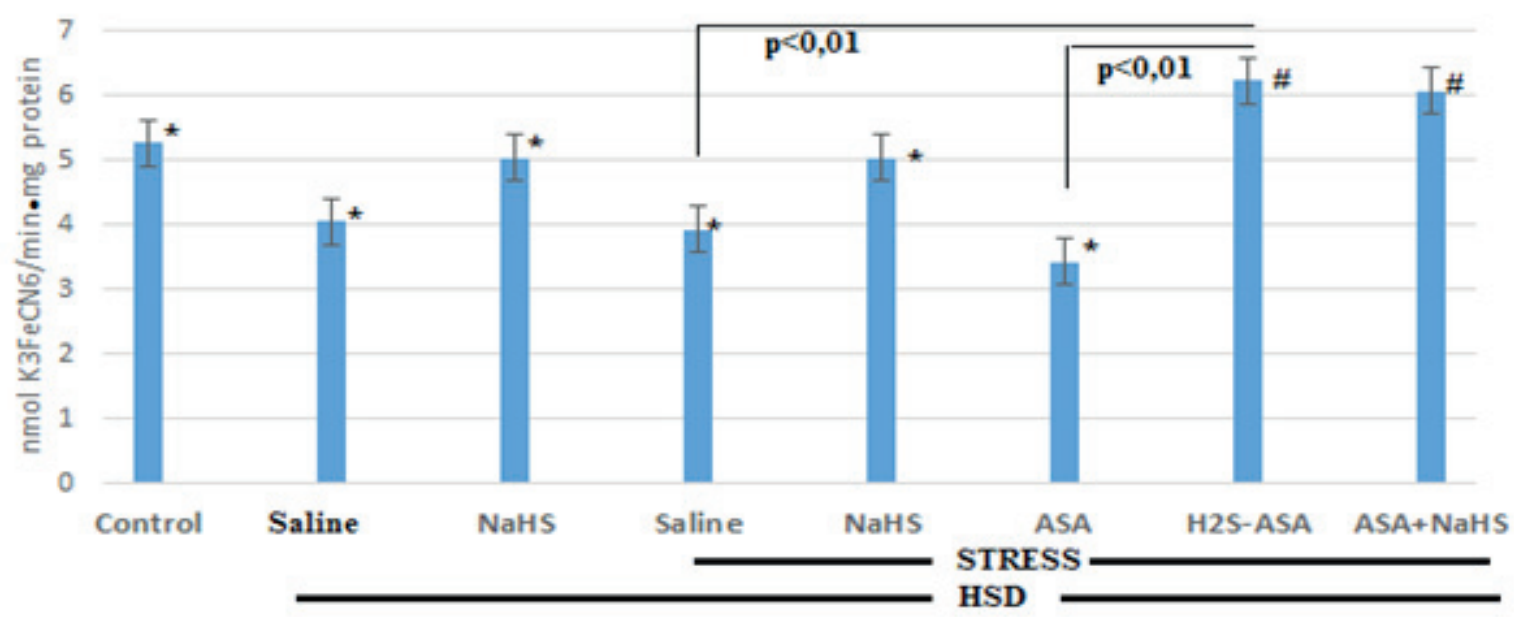

${ }^{*} \mathrm{p}<0,05 \# \mathrm{p}<0,01$ p rs control

Fig. 5. Changes in activities of Sulfide oxidase in mesenterium adipocytes in control and experimental groups of rats 


\section{References}

1. Andrew MS, Huffman DM, Rodriguez-Ayala E, Williams NN, Peterson RM, Bastarrachea RA. Mesenteric visceral lipectomy using tissue liquefaction technology reverses insulin resistance and causes weight loss in baboons. Surgery for Obesity and Related Diseases. 201814 (6): 833-841. https://doi. org/10.1016/j.soard.2018.03.004

2. Augsburger F, Szabo C. Potential role of the 3-mercaptopyruvate sulfurtransferase (3-MST)-hydrogen sulfide $\left(\mathrm{H}_{2} \mathrm{~S}\right)$ pathway in cancer cells. Pharmacological Research. 2018 Nov 27. https://doi.org/10.1016/j. phrs.2018.11.034

3. Banerjee R, Chiku T, Kabil O, Libiad M, Motl N, Yadav PK. Assay methods for H2S biogenesis and catabolism enzymes. In Methods in enzymology Academic Press. 2015 Jan 1 (Vol. 554, pp. 189-200).

4. Beatty JK, Akierman SV, Motta JP, Muise S, Workentine ML, Harrison JJ, Bhargava A, Beck PL, Rioux KP, McKnight GW, Wallace JL. Giardia duodenalis induces pathogenic dysbiosis of human intestinal microbiota biofilms. International journal for parasitology. 2017 May 1;47(6):311-26

5. Bezpalko L, Gavrilyuk O, Zayachkivska O. Inflammatory response in visceral fat tissue and liver is prenatally programmed: experimental research. J Physiol Pharmacol. 2015 Feb 1;66(66):57-64.

6. Calderone V, Martelli A, Testai L, Citi V, Breschi MC. Using hydrogen sulfide to design and develop drugs. Expert opinion on drug discovery. 2016 Feb 1;11(2):163-75.

7. Cheng Y, Ndisang JF, Tang G, Cao K, Wang R. Hydrogen sulfide induced relaxation of resistance mesenteric artery beds of rats. American Journal of Physiology-Heart and Circulatory Physiology. 2017 Nov 10.

8. Coffey JC, O'Leary DP. The mesentery: structure, function, and role in disease. The Lancet Gastroenterology \& Hepatology. 2016 Nov 1;1(3):238-47.

9. Gagliano-Jucá T, Moreno RA, Zaminelli T, Napolitano M, Magalhães AF, Carvalhaes A, Trevisan MS, Wallace JL, De Nucci G. Rebamipide does not protect against naproxen-induced gastric damage: a randomized double-blind controlled trial. BMC gastroenterology. $2016 \mathrm{Dec} ; 16(1): 58$.

10. Gugliandolo E, Fusco R, D'Amico R, Militi A, Oteri G, Wallace JL, Di Paola R, Cuzzocrea S. Anti-inflammatory effect of ATB-352, a H2S- releasing ketoprofen derivative, on lipopolysaccharide-induced periodontitis in rats. Pharmacological research. 2018 Jun $1 ; 132: 220-31$.

11. Ianaro A, Cirino G, Wallace JL. Hydrogen sulfide-releasing anti-inflammatory drugs for chemoprevention and treatment of cancer. Pharmacological research. 2016 Sep 1;111:652-8.

12. Jenkins TA, Nguyen JC, Hart JL. Decreased vascular $\mathrm{H}_{2} \mathrm{~S}$ production is associated with vascular oxidative stress in rats fed a high-fat western diet. Naunyn-Schmiedeberg's archives of pharmacology. 2016 Jul $1 ; 389(7): 783-90$

13. Kimura Y, Shibuya N, Kimura H. Sulfite protects neurons from oxidative stress. British journal of pharmacology. 2018 May 29.

14. Kolluru GK, Shen X, Bir SC, Kevil CG. Hydrogen sulfide chemical biology: pathophysiological roles and detection. Nitric oxide. 2013 Nov 30;35:5-20.

15. Kozar VV, Kudria MY, Ustenko NV, Pavlenko TO, Zhurakovska MV. The state of the humoral component of immunity under conditions of metabolic syndrome with underlying hypoestrogenia and its farmacological correction. Buk Med Herald. 2009;13:141-4.

16. Li M, Xu C, Shi J, Ding J, Wan X, Chen D, Gao J, Li C, Zhang J, Lin Y, Tu Z. Fatty acids promote fatty liver disease via the dysregulation of 3-mercaptopyruvate sulfurtransferase/hydrogen sulfide pathway. Gut. 2018 Dec 1;67(12):2169-80.

17. Lucetti LT, Silva RO, Santana AP, de Melo Tavares B, Vale ML, Soares PM, de Lima Júnior FJ, Magalhães PJ, de Queiroz Cunha F, de Albuquerque Ribeiro R, Medeiros JV. Nitric oxide and hydrogen sulfide interact when modulating gastric physiological functions in rodents. Digestive diseases and sciences. 2017 Jan $1 ; 62(1): 93-104$.

18. Martinez KB, Leone V, Chang EB. Western diets, gut dysbiosis, and metabolic diseases: Are they linked? Gut microbes. 2017 Mar 4;8(2):130-42.

19. Mistry RK, Brewer AC. Redox-dependent regulation of sulfur metabolism in biomolecules: implications for cardiovascular health. Antioxidants \& redox signaling. 2017; Jul 28. https://doi.org/10.1089/ ars.2017.7224

20. Prieto-Lloret J., Aaronson P.I. Potentiation of Hypoxic Pulmonary Vasoconstriction by Hydrogen Sulfide Precursors 3-Mercaptopyruvate and D-Cysteine Is Blocked by the Cystathionine Y Lyase Inhibitor Propargylglycine. In: Peers C., Kumar P., Wyatt C., Gauda E., Nurse C., Prabhakar N. (eds) Arterial Chemoreceptors in Physiology and Pathophysiology. Advances in Experimental Medicine and Biology. 2015; 860. Springer, Cham

21. Takagi K, Kasuya Y, Watanabe K. Studies on the drugs for peptic ulcer. a reliable method for producing stress ulcer in rats. Chemical and Pharmaceutical Bulletin. 1964 Apr 25;12(4):465-72. 
22. Takagi K, Okabe S. The effects of drugs on the production and recovery processes of the stress ulcer. Jpn J Pharmacol 1968; 19: 9-19.

23. Untereiner A, Wu L. Hydrogen sulfide and glucose homeostasis: a tale of sweet and the stink. Antioxidants \& redox signaling. 2018 Jun $1 ; 28(16): 1463-82$.

24. Wallace JL, Blackler RW, Chan MV, Da Silva GJ, Elsheikh W, Flannigan KL, Gamaniek I, Manko A, Wang L, Motta JP, Buret AG. Anti-inflammatory and cytoprotective actions of hydrogen sulfide: translation to therapeutics. Antioxidants \& redox signaling. 2015 Feb 10;22(5):398-410.

25. Wallace JL, de Nucci G, Sulaieva O. Toward more GI-friendly anti-inflammatory medications. Current treatment options in gastroenterology. 2015 Dec 1;13(4):377-85.

26. Wallace JL, Motta JP, Buret AG. Hydrogen sulfide: an agent of stability at the microbiome-mucosa interface. American Journal of Physiology-Gastrointestinal and Liver Physiology. 2017 Oct 12;314(2):G143-9.

27. Wang ZJ, Wu J, Guo W, Zhu YZ. Atherosclerosis and the Hydrogen Sulfide Signaling Pathway-Therapeutic Approaches to Disease Prevention. Cellular Physiology and Biochemistry. 2017;42(3):859-75.

28. Yang G, Ju Y, Fu M, Zhang Y, Pei Y, Racine M, Baath S, Merritt TJ, Wang R, Wu L. Cystathionine gamma-lyase/hydrogen sulfide system is essential for adipogenesis and fat mass accumulation in mice. Biochimica et Biophysica Acta (BBA)-Molecular and Cell Biology of Lipids. 2018 Feb 28;1863(2):165-76.

29. Zaichko N.V., Melnik A.V., Yoltukhivskyy M.M., Olhovskiy A.S., Palamarchuk I.V. Hydrogen sulfide: modern aspects of metabolism, biological and medical role. Ukr. Biochem. J. 2014. 86(5). 5-25.

30. Zayachkivska O, Havryluk O, Hrycevych N, Bula N, Grushka O, Wallace JL. Cytoprotective effects of hydrogen sulfide in novel rat models of non-erosive esophagitis. PloS one. 2014 Oct 21;9(10):e110688.

Стаття надійшла 16.11.2018

Після допрацювання 14.12.2018

Прийнята до друку 27.12.2018 